\title{
Geology, glacier retreat and permafrost degradation as controlling factors of slope instabilities in a high-mountain rock wall: the Monte Rosa east face
}

\author{
L. Fischer, A. Kääb, C. Huggel, and J. Noetzli \\ Glaciology and Geomorphodynamics Group, Department of Geography, University of Zurich, Winterthurerstrasse 190, 8057 \\ Zürich, Switzerland
}

Received: 21 February 2006 - Revised: 3 July 2006 - Accepted: 18 August 2006 - Published: 11 September 2006

\begin{abstract}
The Monte Rosa east face, Italian Alps, is one of the highest flanks in the Alps (2200-4500 m a.s.l.). Steep hanging glaciers and permafrost cover large parts of the wall. Since the end of the Little Ice Age (about 1850), the hanging glaciers and firn fields have retreated continuously. During recent decades, the ice cover of the Monte Rosa east face experienced an accelerated and drastic loss in extent. Some glaciers have completely disappeared. New slope instabilities and detachment zones of gravitational mass movements developed and enhanced rock fall and debris flow activity was observed. This study is based on multidisciplinary investigations and shows that most of the detachment zones of rock fall and debris flows are located in areas, where the surface ice disappeared only recently. Furthermore, most of these detachment zones are located in permafrost zones, for the most part close to the modelled and estimated lower boundary of the regional permafrost distribution. In the view of ongoing or even enhanced atmospheric warming and associated changes it is therefore very likely that the slope instabilities in the Monte Rosa east face will continue to represent a critical hazard source.
\end{abstract}

\section{Introduction}

Perennially frozen and glacierised mountain regions react very sensitively to changes in atmospheric temperature (Haeberli and Beniston, 1998; Harris et al., 2001). As a consequence, climatic developments during the 20th century have caused pronounced effects in the glacial and periglacial belts of high mountain areas. The changes are made strikingly evident by, for example, the retreat of Alpine glaciers (Paul et al., 2004; Zemp et al., 2006). Less immediately visible but also very significant are changes in Alpine permafrost. Dur-

Correspondence to: L. Fischer

(luzfisch@geo.unizh.ch) ing the past century, it has warmed by about 0.5 to $0.8^{\circ} \mathrm{C}$ in the upper tens of meters (Harris and Haeberli, 2003; Harris et al., 2003). Since the Little Ice Age maximum (about 1850), the lower permafrost limit is estimated to have risen vertically by about $1 \mathrm{~m} /$ year (Frauenfelder, 2005).

Steep high-mountain rock walls, which are often characterised by hanging glaciers and firn fields covering extensive parts of the flank as well as widespread permafrost occurrence, are also strongly influenced by these changes. The slope stability of such flanks is influenced by a number of factors. The temperature and stress fields in rock and ice as well as the hydrological regime, however, have a significant influence (Davies et al., 2001). Changes in surface and subsurface ice might change these factors strongly and, especially in combination with unfavourable geological factors discontinuities and lithology - slope instabilities can develop and cause enhanced mass movement activities such as rock fall, debris flows and ice avalanches (Haeberli et al., 1997; Ballantyne, 2002). However, interactions and processes are extremely complex and some major aspects of such slope instabilities are still understudied or even unknown. Especially the interactions between glacier and permafrost in steep flanks and their interaction with other factors are poorly understood.

The shrinkage of hanging glaciers in steep rock walls may uncover large areas of bedrock and leads to changed temperature and stress fields in the rock to great depths (Wegmann et al., 1998; Haeberli et al., 1999; Kääb, 2005). Additionally, the formerly ice covered rock is unprotected from mechani$\mathrm{cal}$ and thermal erosion. The penetration of the freezing front into previously thawed or unfrozen material has the potential to intensify rock destruction through ice formation in cracks and fissures (Hallet et al., 1991; Haeberli et al., 1997; Matsuoka et al., 1998; Kneisel, 2003). Such ice formation, in turn, reduces the near-surface permeability of the rock walls involved and may cause increased hydraulic pressures inside the non-frozen fissured rock sections.

Published by Copernicus GmbH on behalf of the European Geosciences Union. 


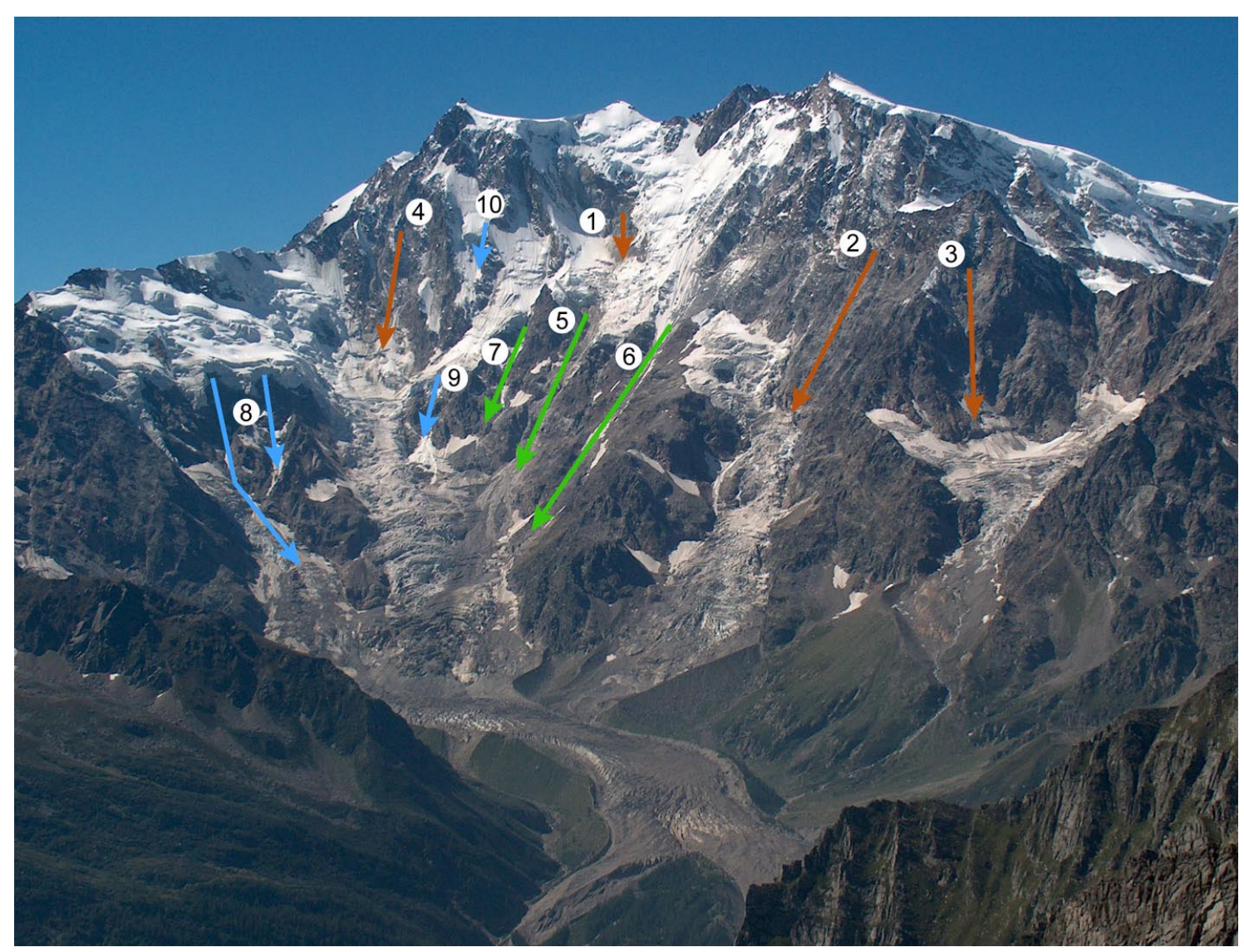

Fig. 1. Monte Rosa east face and Belvedere glacier, seen from Monte Moro. The arrows indicate the main active mass movement zones in the rock wall; rock fall areas are signed in brown, debris flow channels in green and ice avalanche areas in blue. The numbers replace the site names described in Sect. 2.

Permafrost degradation and a rise of the sub-surface ice temperature have - especially in sections of relatively warm permafrost occurrence - a strong influence on the stability of steep rock walls (Wegmann et al., 1998; Davies et al., 2001; Noetzli et al., 2003). Extensive parts of currently perennially frozen rock walls will most probably warm up to depths of many decametres, thereby reaching temperatures of around $0^{\circ} \mathrm{C}$, which are known to be especially critical for stability because of the simultaneous occurrence of ice and water in cracks and fissures. Davies et al. (2001) showed on the basis of direct shear box tests, that a rise in temperature might lead to a reduction in the shear strength of ice-bonded discontinuities and reduce the factor of safety of a rock wall. Warming permafrost is, therefore, likely to lead to increasing scale and frequency of slope failures.

The Monte Rosa east face is an actual example for such changes and developments in a high alpine flank. During the last two decades, the ice cover has strongly changed and the mass movement activity has apparently increased. Scope of this study was in a first step to analyse and illustrate the actual geological and glaciological conditions in the Monte Rosa east face and their developments in the last century. Therefore, three different factors - geology, glaciation and permafrost - were investigated in a multidisciplinary approach using airborne photogrammetry, oblique photos, topographic maps, visual observations, field mapping and modelling. Second purpose was to analyse the linkages and spatial relationships between those three factors, on one hand, and the observed increasing slope instabilities in the Monte Rosa east face, on the other hand. To assess and evaluate the influence of the different examined factors, they are visually analysed and compared. Investigation techniques are well established ones, but the most important contribution of this study is the combined analysis of the above mentioned factors. Many papers, in fact, deal with rock wall stability, but not specifically for high altitude, glacierized rock walls, as this study does. 


\section{Study site and observed mass movement activity}

\subsection{Monte Rosa east face}

The Monte Rosa east face (Fig. 1) is one of the highest steep flanks in the Alps (2200-4500 m a.s.1.), situated in the upper Valle Anzasca above the village Macugnaga, northern Italy (Fig. 2). With the Dufourspitze, Nordend, Zumsteinspitze and Signalkuppe, multiple peaks of over $4500 \mathrm{~m}$ a.s.l. are located at the top of the rock wall. Large parts of the Monte Rosa east face are covered by steep hanging glaciers and firn fields. Since the end of the last maximum glacier extent (Little Ice Age, about 1850), the hanging glaciers and firn fields have retreated slightly (Mazza, 2000). During recent decades, however, the ice cover of the Monte Rosa east face experienced an accelerated and drastic loss in extent and thickness (Haeberli et al., 2002; Kääb et al., 2004; Fischer, 2004). Also the permafrost distribution, even though not directly visible, is believed to have experienced changes in extent and ground-temperatures, as in large parts of the European Alps (Harris et al., 2003).

\subsection{Belvedere glacier}

The Belvedere glacier is located at the foot of the Monte Rosa east face. It is a humid-temperate, heavily debris-covered glacier fed by hanging glaciers, ice and snow avalanches as well as rock falls from the Monte Rosa east face (Mazza, 2000). Between summer 2000 and summer 2001, the Belvedere glacier started a surge-type movement with ice velocities increasing by one order of magnitude and showed in parts a strongly uplifted glacier surface by 10 to $25 \mathrm{~m}$ (Kääb et al., 2004). At the foot of the Monte Rosa east face, however, a large depression developed on the Belvedere glacier and the glacier surface was lowered by 15 to $35 \mathrm{~m}$. Possibly as a consequence of enhanced englacial water pressure or other processes related to the surge-type movement, the supraglacial lake Effimero formed in this depression on the glacier in September 2001 and in the following two summers with a maximum volume of $3 \times 10^{6} \mathrm{~m}^{3}$ (Haeberli et al., 2002; Kääb et al., 2004; Tamburini and Mortara, 2005). The continuously grown topographic depression at the location of the former lake represents a retention basin for small-tomedium rock and ice avalanche events. However, in the case of a water-filled supraglacial lake, a medium mass movement event from the Monte Rosa east face reaching the lake could trigger disastrous chain reactions such as flood or debris flow.

\subsection{Mass movement activity}

Mass movement processes have taken place all times because of the height and steepness of the Monte Rosa east face. Over the recent two decades, however, the mass movement activity in the Monte Rosa east face has drastically increased and new detachment zones of rock falls, debris flows and ice avalanches have developed. The analysis of the mass move-

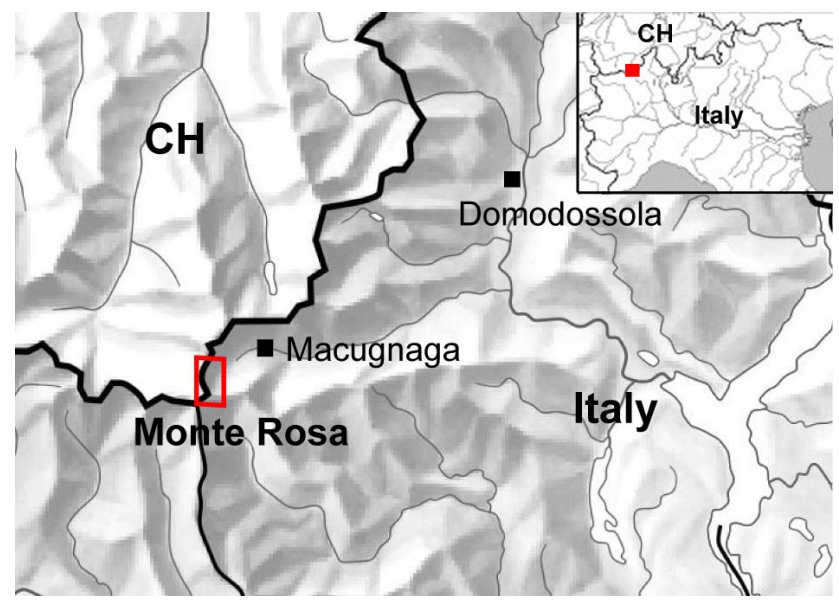

Fig. 2. Sketch map of the investigated area.

ment activity is based on observations during fieldwork in summer 2003 and summer 2004, reports of local people as well as analyses of photos since 1885 and air photos since 1956. It reveals that before about 1985 debris fans hardly existed on the glacier in the lower part of the Monte Rosa east face. Since 1990, pronounced debris fans can be observed.

The main mass movement processes in the face are rock falls, debris flows and ice avalanches (Fig. 1), as observed during fieldwork. The detachment zones of rock fall are situated in the very steep rock walls above $3500 \mathrm{~m}$ a.s.l. and are distributed over the whole Monte Rosa east face. The most active zone of rock falls is from the Parete Innominata (Fig. 1, no. 1) to the hanging glacier below and in the upper part of Channel Imseng (no. 5). In the zones below Jägerjoch (no. 2) and Jägerhorn (no. 3) and on the Signalkuppe east face (no. 4) occasional rock fall can be observed. The debris deposits are mostly accumulated in the channels and on the hanging glaciers in the face, no observed rock fall events have reached the foot of the rock wall.

During spring, summer and autumn, rock fall events, which are strongly varying in size and reach, occur repeatedly. During fieldwork in the extraordinary hot summer 2003, rock fall events from different detachment zones could be observed almost every day. Even during the winter the gravitational mass movements - though reduced - take place. This indicates in some places a strongly reduced stability in the bedrock and shows that rock fall activity is not only affected by thawing and melting water during summertime, but rather by changed glacier, permafrost and bedrock conditions.

The debris flows mostly occur in the channels Imseng and Marinelli (Fig. 1, no. 5 and 6), occasionally also in the channel Zapparoli (no. 7). This mass movement process forms from debris deposits in the channel, which are accumulated because of the rock fall activities and physical weathering of the bedrock. The debris flows are a mixture of rock 


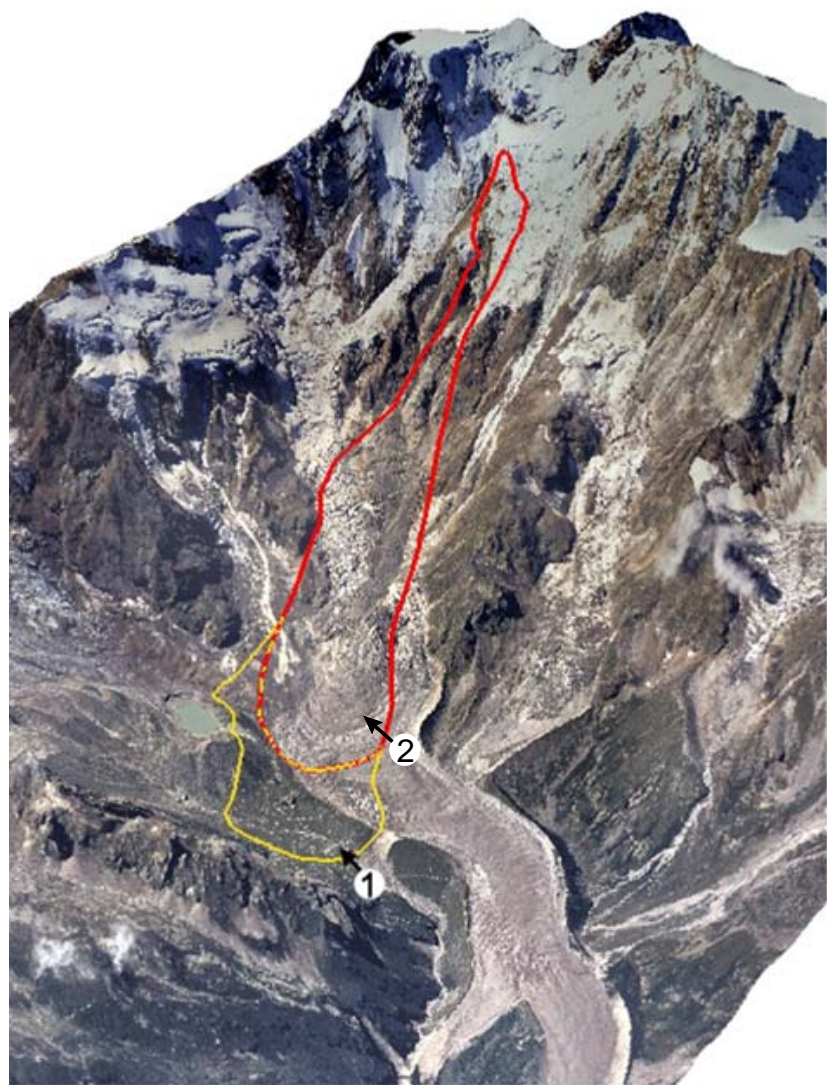

Fig. 3. Transition zone and deposit area of the ice/rock avalanche in August 2005. The reach of the solid part of the avalanche (rock and ice) is marked in red; the reach of the powder avalanche is marked in yellow. No. 1 indicates the location of the hut Zamboni, no. 2 points to the location of the Lake Effimero, which is not visible on this aerial photograph from 1999.

and water, some are additionally mixed with considerable amounts of ice. They occur particularly during summertime when a lot of melting water is available in the Monte Rosa east face. During summer of 2003 - the extraordinary hot summer - almost daily activity was observed.

In steep high-mountain areas, relatively small and frequent ice avalanches often correspond to the natural ablation of steep hanging glaciers (Alean, 1985; Margreth and Funk, 1999), as seen on the Monte Rosa east face (Fig. 1, Ghiacciaio del Signal, no. 8; Ghiacciaio del Monte Rosa, no. 9). However, some large-scale events have occurred recently, especially in the area of channel Imseng (Fig. 1, no. 5). Between 1999 and 2001, about $350 \mathrm{~m}$ in length of this hanging glacier disappeared, most likely as a result of several ice avalanche events. A major ice avalanche, whose breakoff volume was estimated to be of the order of $1.1 \times 10^{6} \mathrm{~m}^{3}$ (A. Tamburini, personal communication), occurred in $\mathrm{Au}$ gust 2005 in the same area. The avalanche volume increased furthermore along its path by eroding underlying debris and ice. The main part of the material was deposited on the glacier Belvedere, particularly in the - fortunately almost empty - depression of the former lake Effimero (Fig. 3, red marking). The powder-part of the avalanche including ice and debris fragments, however, overtopped the lateral moraine of the Belvedere glacier and covered the plain around the hut Zamboni (Fig. 3, yellow marking). Fortunately, this ice avalanche occurred at night when nobody stayed at the frequently visited plain around the Rifugio. During the day, with a lot of tourists upwards to the plain and moraine, a number of injured persons or even casualties could have been possible.

\section{Methods}

Three different predisposing factors were studied in a multidisciplinary approach in order to assess their influence on the slope stability of the Monte Rosa east face: (i) geology, (ii) permafrost distribution and (iii) changes in glaciation. In a first step, the three factors were analysed separately to assess the recent changes and contemporary conditions. The results of this step are discussed in Sect. 4. In a second step, the results from the first analyses were compiled for a comparison with the current detachment zones of the ongoing mass movements. These analyses have been done visually by comparing the three analysed factors with the positions of the actual detachment zones. The detachment zones are indicated in each figure of the three investigated factors and therefore a direct comparison can be done. The findings of this second step are discussed in Sect. 5.

\subsection{Detachment zones}

The detachment zones were detected and analysed based on the combination of daily visual observations during fieldwork, photogrammetry and oblique photos. The fieldwork has taken place in summer 2003 and summer 2004, therefore the investigated detachment zones are the actual ones of these years. Detachment zones, transfer channels and frequency of the gravitational mass movement processes were observed and recorded during fieldwork (cf. Sect. 2 and Fig. 1). Due to the uncertainties from remote mapping and the multiple events at rather the same zone, detachment zones are only marked with a dot or circle. For the comparison with the geology, the detachment zones are classified in two groups, those from ice avalanche and those from rock falls/debris flows. The detachment zones of rock falls and debris flows are combined due to the fact that most debris flows are closely connected to the rock fall zones because of the available debris.

\subsection{Geology}

Geology is a fundamental parameter for slope stability. Therefore, the geological setting of the Monte Rosa east face was investigated during field work and a geological map was 

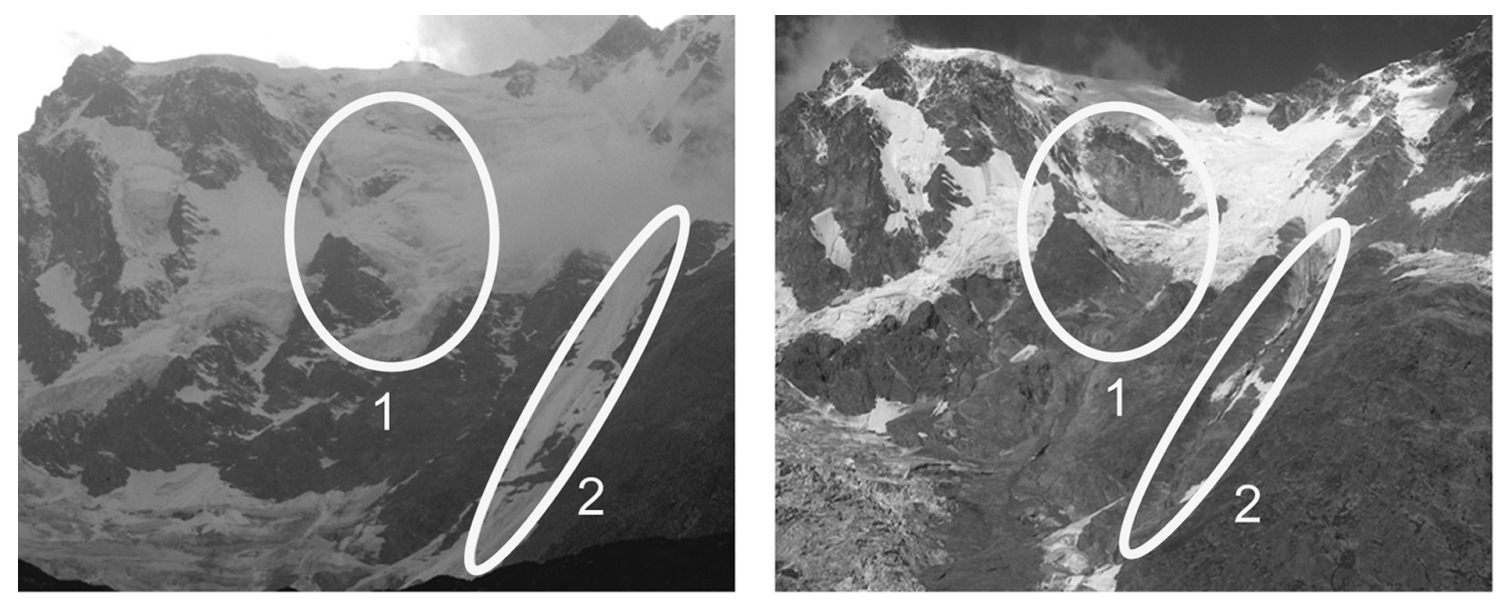

Fig. 4. Glacier extents on the Monte Rosa east face in September 1983 (left, W. Haeberli) and August 2003 (right, L. Fischer). Marking 1 indicates the Parete Innominata and the upper part of the Imseng channel, 2 indicates the Marinelli channel, zones with the most striking changes in glacier extent and also the highest mass movement activity.

compiled. Due to inaccessibility of most parts of the Monte Rosa east face it was mostly mapped remotely from the opposite slope. As a basis for the mapping the topographic maps Zermatt (Swisstopo, sheet no. 1348) and Monte Moro (Swisstopo, sheet no. 1349) were used. Furthermore, the Geological Atlas of Switzerland (Schweizerische Geologische Kommission), scale 1:25 000, and the study of Bearth (1952) were used for the classification of the lithology. For further investigations the geological field map was digitised in the GIS (Geographic Information System).

\subsection{Permafrost distribution}

To assess the permafrost distribution in the Monte Rosa east face and its possible linkage to the slope stability problems, two different models were applied aiming at estimating the lower boundary of the permafrost occurrence. This area is characterized by warm permafrost with temperatures marginally below $0^{\circ} \mathrm{C}$ and liquid water content thus presumably present and therefore is the most sensitive zone to permafrost degradation.

In a first approach the model PERMAKART (Keller, 1992) was applied. PERMAKART is based on the so-called "rules of thumb" to predict permafrost occurrences as developed earlier for the eastern Swiss Alps by Haeberli (1975). Based on an input DEM, PERMAKART primarily considers radiation effects as related to aspect, air temperature as related to altitude and snow cover as related to slope foot areas (long lasting snow cover caused by avalanche deposits). As these empirical rules are deduced and calibrated for the Upper Engadine in the Eastern Swiss Alps, they are first fitted to the Monte Rosa region using the $0^{\circ} \mathrm{C}$-isotherm altitude and temperature gradient from the meteo station of Plateau Rosa/Testa Grigia at $3488 \mathrm{~m}$ a.s.l. (Mercalli et al., 2003). Based on a MAAT of $-5.8^{\circ} \mathrm{C}$ of the Plateau Rosa station and lapse rate of $0.57^{\circ} \mathrm{C} / 100 \mathrm{~m}$ (Mercalli et al., 2003), a $0^{\circ} \mathrm{C}$ isotherm altitude of $2470 \mathrm{~m}$ a.s.l. results. The calculations were based on a $25 \mathrm{~m}$ gridded DEM (DHM25 Level 2, Swisstopo) with a vertical accuracy of 4-6 m. However, due to the extreme topography in the Monte Rosa east face and its marginal position on the Swiss boundary larger errors of vertical elevations exist.

A second model is deduced from rock temperature calculations by Gruber et al. (2004) and called ROCKFROST in this paper. On the basis of meteo data, energy fluxes were modelled and eventually the spatial distribution of mean annual rock surface temperatures was calculated for climate conditions in the central (Corvatsch, Engadine) and northern Alps (Jungfraujoch, Bernese Alps) for a time period of 1982-2002. On a long-term basis the mean elevation of the $0^{\circ} \mathrm{C}$-isotherm of the ground surface temperature corresponds to the lower limit of permafrost distribution in steep rock. By approximating the relation between the elevation of the $0^{\circ} \mathrm{C}$ isotherm and aspect with a polynomial function for different slope values, the permafrost occurrence in steep rock can be assessed within a GIS. For these calculations the same DEM was used as in the first approach. Grid cells with a minimum slope of $45^{\circ}$ were considered as steep rock.

\subsection{Glacier extent}

In order to reconstruct changes in glacier extents on the Monte Rosa east face, oblique photos (e.g. Figs. 4 and 5), historic maps and orthorectified air-photos were analysed. The glacier extents for different years were reconstructed by two approaches using different data sets. Both approaches were conducted by digitising glacier contours for different years since the early 20 th century.

In a first approach, glacier extents were reconstructed on the basis of field observations in summer 2003, various old 

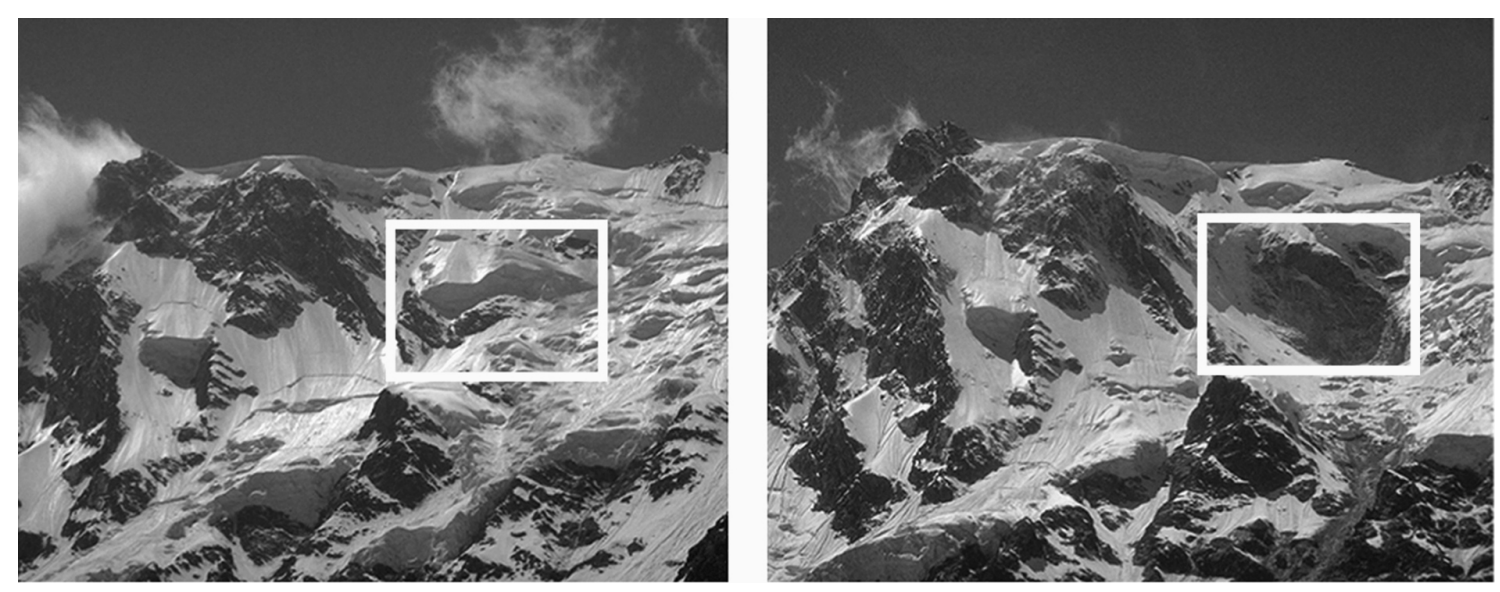

Fig. 5. Comparison of the glacier extent in the upper part of the Monte Rosa east face between June 1986 (left, H. Röthlisberger) and July 2002 (right, W. Haeberli). The white square indicates Parete Innominata, where a whole hanging glacier disappeared uncovering this steep rock wall.

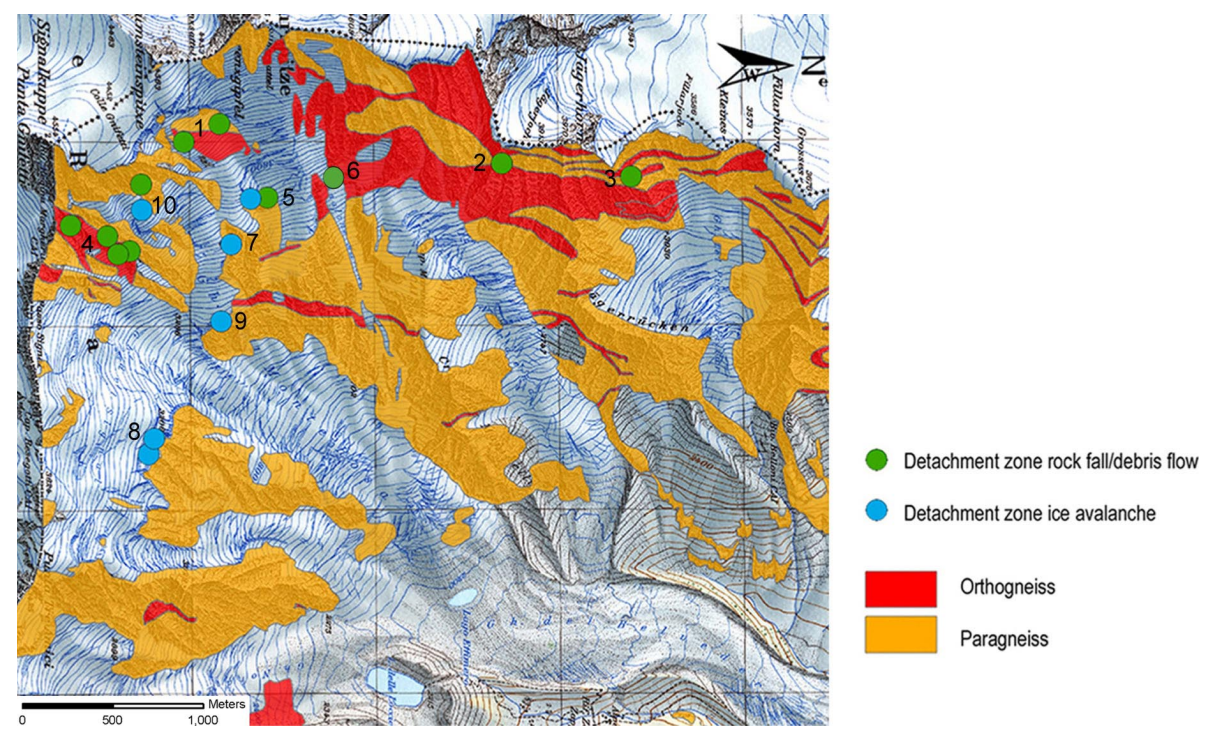

Fig. 6. Detachment zones of rock fall/debris flow events and ice avalanches in the Monte Rosa east face. The locations are marked by green and blue dots. Furthermore, the geology of the Monte Rosa is shown, orthogneiss in red and paragneiss in orange colour. Numbering is corresponding to Fig. 1. Topographic map is reproduced by permission of Swisstopo (BA067953).

oblique photos since 1885 and a historical topographic map. The procedure is mainly based on the visual comparison of different photos. The Italian topographic map dated from 1924 was georeferenced thus allowing glacier outlines to be digitised. The delineation of glacier extent in 1982 and 1999 was exclusively based on oblique photos. These photos were examined visually and the outlines were estimated manually in the GIS based on the digital topographic maps "Zermatt" and "Monte Moro". The glacier extent of 2003 was mapped during the field work and from oblique photos. An overlay of the different years shows the resulting glacier extents and corresponding retreat through time.
In a second approach, air-photos (taken by the Swisstopo) of the years 1956, 1977, 1988, 1999 and 2001 were orthorectified with the program PCI OrthoEngine on the basis of the DHM25 Level 2 from Swisstopo and map-derived ground control points. The identification of ground control points in the air-photos for the orthorectification turned out to be difficult due to the steepness of the Monte Rosa east face and consequent strong distortions of the air-photos. Due to some larger errors in vertical elevations in the DEM some horizontal inaccuracies occur in the orthophotos. However, this can be accounted for while delineating the outlines of the glaciers manually in the GIS. 


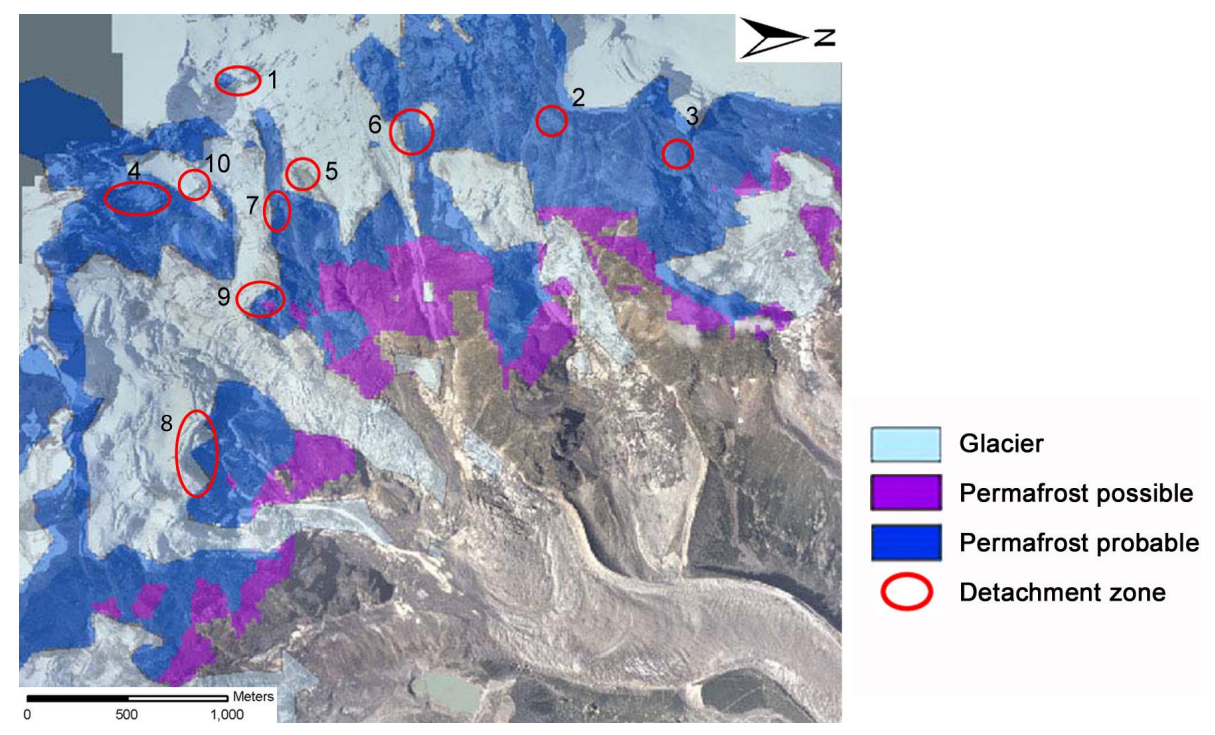

Fig. 7. Permafrost distribution based on the PERMAKART model with indicated active detachment zones, numbering is corresponding to Fig. 1. DHM25 @) swisstopo (BA067953).

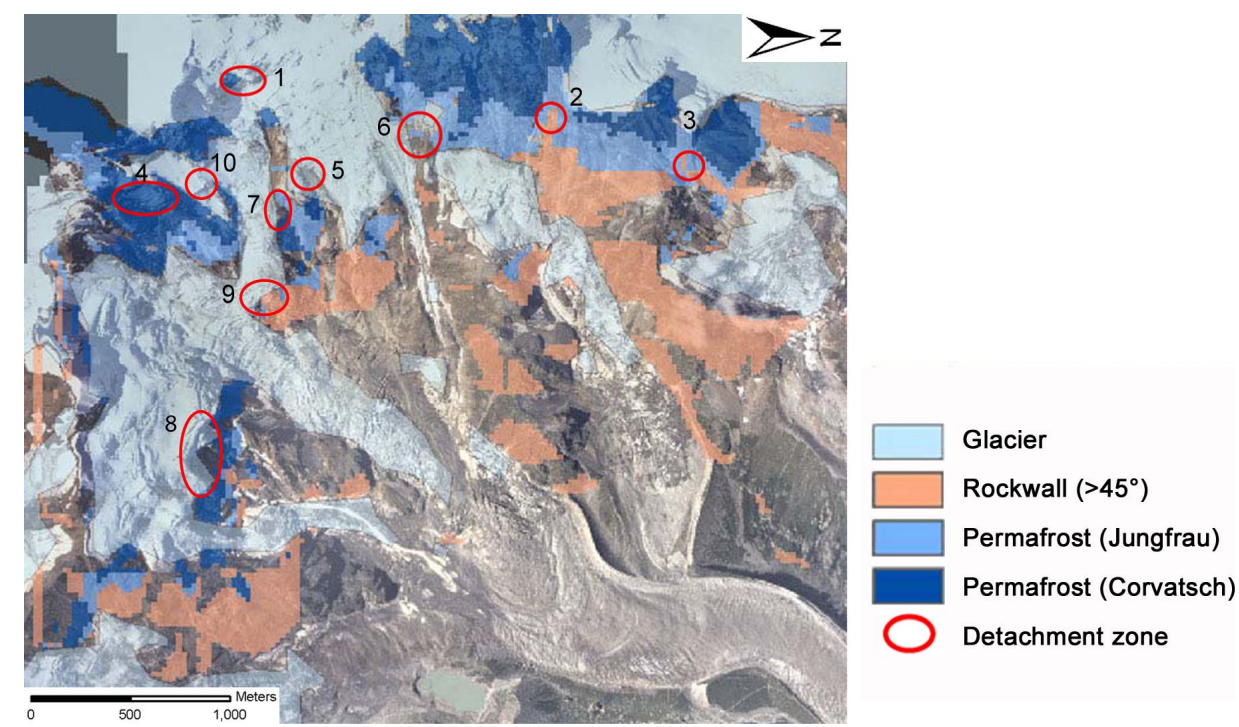

Fig. 8. Permafrost distribution based on the ROCKFROST model with indicated active detachment zones. DHM25 ( swisstopo (BA067953).

\section{Results}

\subsection{Geology}

The geology of the Monte Rosa east face is characterized by layers of two different lithologies: orthogneiss and paragneiss (Bearth, 1952; Fischer, 2004). The two lithologies stem from the cristallyne of the penninic Monte Rosa nap. Orthoand paragneiss can be well distinguished in the field based on the containing minerals, structures and their colour.

The composition of orthogneiss varies considerably throughout the Monte Rosa east face but the predominant constituent minerals are always quartz, kalifeldspar, plagioclase, muscovite and biotite. The structure of the orthogneiss varies from bulky to parallel texture. Paragneiss contains either biotite or muscovite as a main part, often combined as well and garnet, quartz and feldspar as a minor part. The paragneiss shows a pronounced parallel texture (schistosity) with varying formation from schist to gneiss. The geological setting of the Monte Rosa is strongly alternating between the two lithologies (Fig. 6). In most parts of the rock wall, the lithological stratification is clearly visible. Hence, many transition zones between the two lithologies occur. 


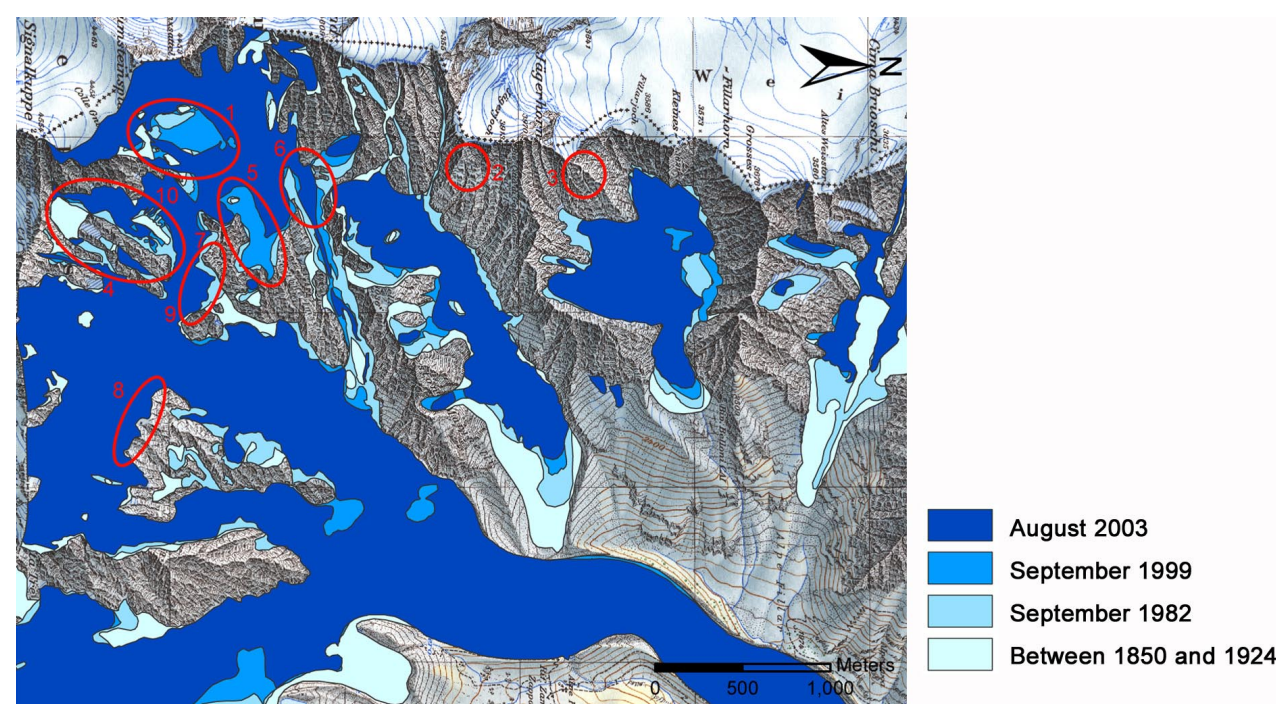

Fig. 9. Reconstruction of glacier extent derived from oblique photos and a historic map from 1924. The active detachment zones are indicated in red. Topographic map is reproduced by permission of Swisstopo (BA067953).

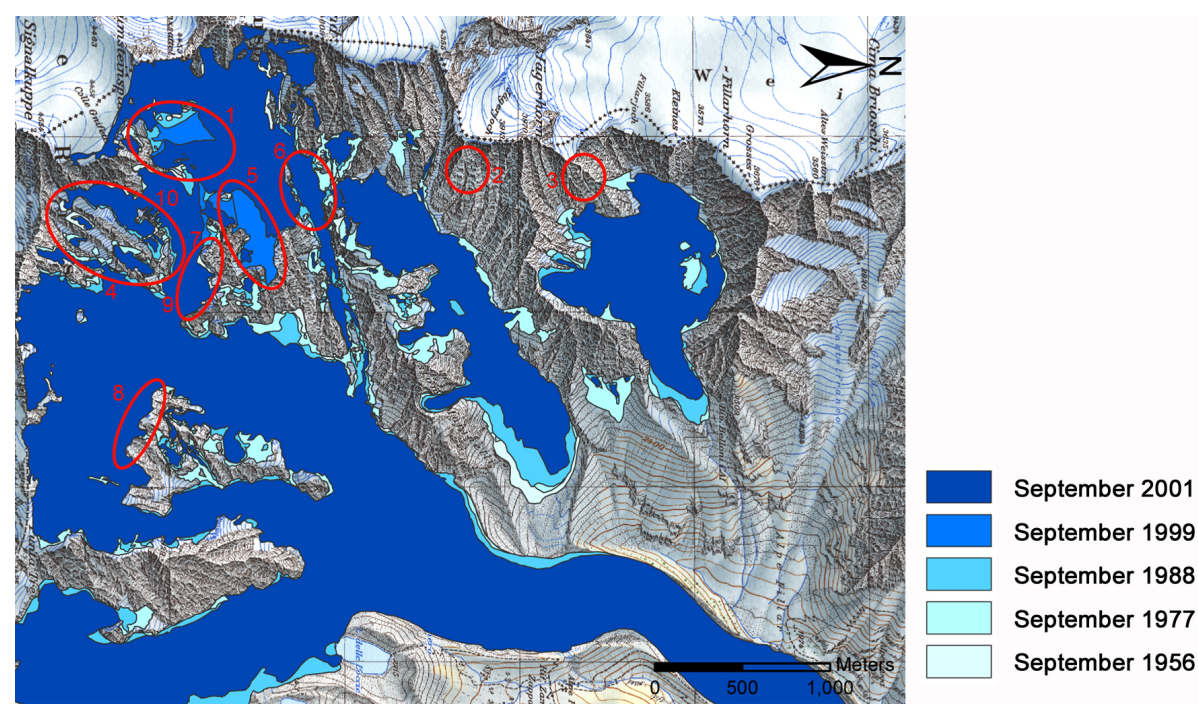

Fig. 10. Reconstruction of the glacier extent derived from orthorectified airphotos. The active detachment zones are indicated in red. Topographic map is reproduced by permission of Swisstopo (BA067953).

\subsection{Permafrost distribution}

Applying PERMAKART, the lower boundary of the possible permafrost occurrence (where locally permafrost may occur) is modelled at an altitude of 2700-2800 m a.s.l. (Fig. 7). The lower limit of probable permafrost (where continuous permafrost is supposed) is located between 2900 and $3200 \mathrm{~m}$ a.s.l., depending on the exposition and inclination of the rock wall. Since the model is based on rules of thumbs deduced in rather gentle as well as debris- and snowcovered slopes the PERMAKART model tends to overestimate the permafrost distribution in steep rock and, hence, can be consulted for an indication of the maximum permafrost occurence in the Monte Rosa east face.

Based on the ROCKFROST calculations, the lower boundary of the permafrost distribution is estimated to be between 3000-3300 (Jungfrau) and 3200-3500 m a.s.l. (Corvatsch) depending on the exposition and inclination of the rock wall (Fig. 8). The two classes Jungfrau and Corvatsch correspond to inner and slightly colder northern Alpine climate conditions, respectively. For the lower limit of permafrost occurrence, the model results for northern Alpine conditions are regarded to be the more likely for near-vertical snow-free areas of such steep rock walls like the Monte Rosa east face. 
However, the ROCKFROST model might slightly underestimate the permafrost distribution, since shadowing effects and potential local small snow deposits lower ground temperatures but are not taken into account. According to the calculations by Gruber et al. (2004) the uncertainties of this approach are in the range of $\pm 2^{\circ} \mathrm{C}$, which corresponds to roughly $\pm 200 \mathrm{~m}$ vertically.

Together, the models indicate the sensitive areas around the lower boundary of the permafrost occurrence that can be localised between about 3100-3600 $\mathrm{m}$ a.s.l. This large range is mainly due to the different aspects found on the flank.

\subsection{Glacier extent}

The reconstruction of the glacier retreat based on the first approach is shown in Fig. 9. This map shows the continuous retreat of hanging glaciers and firn fields since the end of the Little Ice Age. Unlike the strong retreat of many valley-type glaciers since about 1850, the changes of the steep glaciers in the Monte Rosa east face were not very distinctive from this time until the 1980s. However, during the last few decades an accelerated loss in extent of the ice cover becomes evident. Some glaciers (or parts of glaciers) disappeared within only a few years and they seem to decay through mass wasting. The analysis based on field observations, various old oblique photos and a historic map represents a qualitative analysis and the result provides a good overview of the changes in glaciation since the last glacier maximum (Little Ice Age). Another advantage of this approach is the existence of maps and oblique photos since the end of the 19th century.

The results of the second approach are shown in Fig. 10 and reveal a slight but progressive deglaciation in the Monte Rosa east face since 1956 and in some parts of the face a drastic loss of the ice-covered area in the last 10-15 years. The analysis of the orthophotos also reveals an occasional increase in the extent of certain firn fields and some hanging glaciers. This approach demonstrates that airborne remote sensing and analyses of orthophotos offer efficient methods for glacier mapping even on steep flanks. The mapping based on orthophotos is more detailed than that with oblique photos. However, due to the higher degree of details the general picture of change decreases in places. Another disadvantage is the lack of air-photos before 1956.

Together, the two methods give an overview over the glacier retreat and reveal the areas with the most pronounced changes in glaciation. In Canalone Marinelli the ice-covered area has decreased drastically since about 1995 . The most striking changes took place in the hot summer of 2003 when the entire channel became almost ice-free. In Canalone Imseng a large part of the glacier tongue disappeared between 1999 and 2001 leaving a zone of instable rock. In the same zone, the ice avalanche in August 2005 with a break-off volume of more than $1 \times 10^{6} \mathrm{~m}^{3}$ occurred. The ice cover of the Parete Innominata, currently the most active rock fall zone, has retreated stronly since 1990 and the present active detachment zone has become ice-free since around 2000.

\section{Discussion}

In this section, the analyses of relationships between the development of slope instabilities, on one hand, and geology, glacier retreat and permafrost degradation, on the other hand, are presented and discussed. Figure 6 shows the geological setting in the Monte Rosa east face and the positions of the actual detachment zones. It reveals that all detachment zones of rock falls and debris flows (green dots) are situated in the upper part of the rock wall, between 3400 to $4100 \mathrm{~m}$ a.s.l. In addition, a concentration of detachment zones at transition zones between orthogneiss and paragneiss becomes apparent (Fig. 6, detachment zones no. 1-5 and 7, see also Table 1). This indicates that the transition zones between orthogneiss and paragneiss could favour or cause instabilities because of the different geotechnical properties of the two lithologies. The detachment zones of ice avalanches are also situated in the upper part of the flank, but most of them cannot directly be related to the geological setting. In some zones, though, where ice avalanches are influenced by rock fall and debris flows, lithological transition zones may have an indirect impact on the glaciers.

The comparison of changes in glacier extent with current detachment zones shows that many rock fall and most debris flow events originate in recently deglaciated parts of the Monte Rosa east face (Figs. 9 and 10, Table 1). Today, Parete Innominata (1), channel Imseng (5) and channel Marinelli (6) represent the most active zones of both, glacial changes and mass movement activity. An important observation is the spatial shifting of the active detachment zones with decreasing glacier extent. Around 1990, the channel Zapparoli (7) was the only active detachment zone. At that time, the hanging glacier above the channel Zapparoli decreased drastically in extent and induced enhanced mass movement activity. Today, this zone is not very active anymore. This observation points out that changes in glacier extent might affect slope stability significantly due to drastic changes in surface and also subsurface conditions in the deglaciated areas. The major ice avalanches observed during recent decades occurred particularly in zones with significant glacial changes, the Parete Innominata (1) and channel Imseng (5). The Ghiacciaio del Signal (8), however, is hardly affected by changes in glacier extent. These ice avalanches occur as natural ablation due to the cliff position of this glacier. This shows that the reactions of hanging glaciers on a rise in atmospheric temperature are varying considerably.

Furthermore, modelling analyses suggest a probable linkage between permafrost degradation and the formation of detachment zones (Figs. 7 and 8). These figures reveal that many detachment zones of the present rock fall and debris flow events (2-7) and also some starting zones of ice 
Table 1. Compilation of the active detachment zones of the summer 2003. This compilation reveals the influence of the three investigated factors geology, glacier retreat and permafrost on slope stability. For each active detachment zone the possible influencing factors are marked with $\times$.

\begin{tabular}{|c|c|c|c|c|}
\hline Detachment zone & & $\begin{array}{l}\text { Geology } \\
\text { (close to a transition } \\
\text { zone) }\end{array}$ & $\begin{array}{l}\text { Glacier } \\
\text { (areas with glacier } \\
\text { retreat) }\end{array}$ & $\begin{array}{l}\text { Permafrost } \\
\text { (most probably warm } \\
\text { permafrost) }\end{array}$ \\
\hline Parete Innominata, upper part (1) & \multirow{7}{*}{ 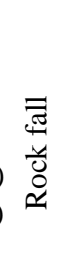 } & $x$ & $x$ & \\
\hline Parete Innominata, lower part (1) & & $x$ & $x$ & \\
\hline Jägerjoch (2) & & $x$ & & $x$ \\
\hline Jägerhorn (3) & & $x$ & & $x$ \\
\hline Signalkuppe east face, upper part (4) & & & $x$ & \\
\hline Signalkuppe east face, lower part (4) & & $\times$ & $x$ & $\times$ \\
\hline Channel Imseng (5) & & $\times$ & $x$ & $\times$ \\
\hline Channel Marinelli (6) & \multirow{3}{*}{ 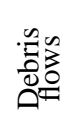 } & & $x$ & $x$ \\
\hline Channel Imseng (5) & & $\times$ & $x$ & $\times$ \\
\hline Channel Zapparoli (7) & & $x$ & $x$ & $x$ \\
\hline \multicolumn{5}{|l|}{ Ghiacciaio del Signal (8) } \\
\hline Ghiacciaio del Monte Rosa (9) & \multirow{5}{*}{ 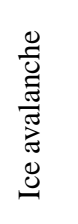 } & & & $\times$ \\
\hline Channel Zapparoli (7) & & $x$ & $\times$ & $x$ \\
\hline Channel Imseng, upper part (5) & & $x$ & $x$ & \\
\hline Channel Imseng, lower part (5) & & & $x$ & $\times$ \\
\hline Signalkuppe hanging glacier (10) & & & $x$ & \\
\hline
\end{tabular}

avalanches $(5,7$, and 9) are situated in areas of most probably warm permafrost at the lower boundary of permafrost occurrence (Table 1). This fact confirms the assumption, that instabilities may be formed in part due to increased temperatures in warm permafrost occurrence, which in turn may lead to decreased shear strength in the rock wall and enhanced water pressure. However, some of the detachment zones of rock fall are situated at higher altitudes where occurrence of cold permafrost is predicted. This suggests that not all rock fall events are directly connected to changes in ground-thermal conditions. A rise in permafrost temperatures may also laterally influence the thermal regime of hanging glaciers and have a destabilizing effect on cold hanging glaciers. Rising temperatures can thereby induce higher ice temperatures and more percolating melt water at the glacier bed and thus increase the stresses at the front of steep glaciers.

The performed analyses based on the combination of different methods such as airborne photogrammetry (Kääb et al., 2005), oblique ground-based photo comparisons, local field surveys and modelling in the GIS represent a useful approach for visually detecting the spatial and temporal relationship between different factors and processes in steep rock walls. Each investigated factor and process can be illustrated as a separate GIS-layer and an overlay of two or more layers reveals spatial as well as temporal linkages between investigated processes and their influence on the formation of new detachment zones. The visual processing and presentation of different processes and factors in the Monte Rosa east face with GIS-techniques provides a basis for direct comparisons.

\section{Conclusion and perspectives}

In the following the most important results of this study are summarised (see also Table 1):

- During recent decades, the ice cover of the Monte Rosa east face experienced an accelerated and drastic loss in extent.

- Enhanced mass movement activity was observed since about 1990 and new detachment zones were developed.

- Most of the detachment zones on the Monte Rosa east face are located in areas where surface ice has recently disappeared.

- Many detachment zones are located at the altitude of the lower boundary of the estimated permafrost distribution, where presumably warm and degrading permafrost exists.

- Many detachment zones are situated in transition zones between orthogneiss and paragneiss.

- The formation of detachment zones mostly seems to be caused by a combination of different factors.

The presence of lithological transitions zones seems to be a crucial factor for the development of instabilities in rock. However, also glacier retreat and permafrost degradation as a consequence of atmospheric warming have significant consequences on slope stability. The magnitude of observed rock 
fall events during recent decades was rather small but they occurred frequently. These events could have happened as a consequence of permafrost thawing at the lower boundary of the permafrost distribution as well as the thawing of the near-surface permafrost layers in other parts of the rock wall. Changes in permafrost temperature into greater depths caused by long-term temperature changes could also cause large-size rock fall events.

In many unstable areas, a combination of the three main mass movement processes - rock falls, debris flows and ice avalanches - can be observed. Detachment zones of debris flows are mostly connected to the zones of rock fall due to the available debris. Ice avalanches occur on one hand due to the natural ablation of hanging glaciers, on the other hand however, some of them seem to be strongly related to instabilities in bedrock. In some parts of the Monte Rosa east face, e.g. channel Imseng, ice avalanche activity is influenced by rock falls and debris flows. Thus, an indirect influence of geology and permafrost on ice avalanche activity can be assumed. The compilation in Table 1 reveals that almost all observed detachment zones of rock fall, debris flows and ice avalanches in the Monte Rosa east face seem to be influenced by at least one of the investigated factors, but mostly by two or all of them. This indicates the importance of the combination and interaction of different processes and factors affecting the stability of steep slopes and the formation of detachment zones.

However, the three investigated factors represent still just a subset out of a complex net of different factors, processes and feedback mechanisms in a steep rock wall. For further analyses and mainly for the prediction of hazardous zones, more factors and processes - such as geological, geomechanical, geomorphologic, topographic, glaciological and climatic factors - have to be investigated and their influence on rock wall stability has to be assessed. A particularly important aspect is the geomechanical setting. Discontinuities such as layering, schistosity and rock joints are crucial predisposing factors for slope stability in steep rock walls, especially for the size and potential failure mode of rock falls (e.g. Abramson et al., 2001). Hence, further investigations should be directed to geomechanical aspects and the dependence on changes in surface and subsurface ice.

Due to the ongoing or even enhanced changes in surface and subsurface ice related to the atmospheric warming, large magnitude events in rock and ice cannot be ruled out in the Monte Rosa east face, as indicated with the large ice avalanche in August 2005. Chain-reactions of mass movement processes have also to be taken into account for further investigations. In case of a major supraglacial lake on the Belvedere glacier at the foot of the rock wall, as in summer 2002 and 2003, large mass movement events from the Monte Rosa east face could trigger disastrous chain reactions such as floods or debris flows, which could endanger populated areas.
Edited by: G. Wieczorek

Reviewed by: M. Chiarle and another referee

\section{References}

Abramson, L. W., Lee, T. S., Sharma, S., and Boyce, G. M.: Slope stability and stabilization methods, John Wiley \& Sons, New York, 2001.

Alean, J.-C.: Ice avalanches: some empirical information on their formation and reach, J. Glaciol., 31, 324-333, 1985.

Ballantyne, C. K.: Paraglacial geomorphology, Quart. Sci. Revi., 21, 1935-2017, 2002.

Bearth, P.: Geologie und Petropraphie des Monte Rosa, Beiträge zur Geologischen Karte der Schweiz, Bern, 1952.

Davies, M. C. R., Hamza, O., and Harris, C.: The effect of rise in mean annual temperature on the stability of rock slopes containing ice-filled discontinuities, Permafrost and Periglacial Processes, 12, 137-144, 2001.

Fischer L.: Monte Rosa Ostwand - Geologie, Vergletscherung, Permafrost und Sturzereignisse in einer hochalpinen Steilwand, M.Sc.-Theses, Department of Geography, University of Zurich, 2004.

Frauenfelder, R.: Regional-scale modelling of the occurrence and dynamics of rockglaciers and the distribution of paleopermafrost, Schriftenreihe Physische Geographie, Glaziologie und Geomorphodynamik, University of Zurich, 2005.

Gruber, S., Hoelzle, M., and Haeberli, W.: Rock-wall temperature in the Alps: modeling their topographic distribution and regional differences, Permafrost and Periglacial Processes, 15, 299-307, 2004.

Haeberli, W.: Untersuchungen zur Verbreitung von Permafrost zwischen Flüelapass und Piz Grialetsch (Graubünden). Zürich: Mitteilung Nr. 17 der Versuchsanstalt für Wasserbau, Hydrologie und Glaziologie der ETH Zürich, 1975.

Haeberli, W. and Beniston, M.: Climate change and its impacts on glaciers and permafrost in the Alps, Ambio, 27/4, 258-265, 1998.

Haeberli, W., Wegmann, M., and Vonder Muehll, D.: Slope stability problems related to glacier shrinkage and permafrost degradation in the Alps, Eclogae geologicae Helvetiae, 90, 407-414, 1997.

Haeberli, W., Kääb, A., Hoelzle, M., Bösch, H., Funk, M., Vonder Mühll, D., and Keller, F.: Eisschwund und Naturkatastrophen im Hochgebirge. Schlussbericht NFP31, vdf Hochschulverlag ETH Zürich, 1999.

Haeberli, W., Kääb, A., Paul, F., Chiarle, M., Mortara, G., Mazza, A., Deline, P., and Richardson, S.: A surge-type movement at Ghiacciaio del Belvedere and a developing slope instability in the east face of Monte Rosa, Macugnaga, Italian Alps, Norwegian Journal of Geography, 56, 104-111, 2002.

Hallet, B., Walder, J. S., and Stubbs, C. W.: Weathering by segregation ice growth in microcracks at sustained subzero temperatures: Verification from experimental study using acoustic emissions, Permafrost and Periglacial Processes, 2/4, 283-300, 1991.

Harris, C. and Haeberli, W.: Warming permafrost in the mountains of Europe, World Meteorological Organization Bulletin, 52(3), 252-257, 2003.

Harris, C., Davies, M., and Etzelmüller, B.: The assessment of potential geotechnical hazards associated with mountain permafrost 
in a warming global climate, Permafrost and Periglacial Processes, 12, 145-156, 2001.

Harris, C., Vonder Mühll, C., Isaksen, K., Haeberli, W., Sollid, J. L., King, L., Holmlund, P., Dramis, F., Gugliemin, M., and Palacios, D.: Warming permafrost in European mountains, Global and Planetary Change, 39, 215-225, 2003.

Kääb, A.: Remote sensing of mountain glaciers and permafrost creep, Schriftenreihe Physische Geographie, University of Zurich, 48, 264 pp, 2005.

Kääb, A., Huggel, C., Barbero, S., Chiarle, M., Cordola, M., Epifani, F., Haeberli, W., Mortara, G., Semino, P., Tamburini, A., and Viazzo, G.: Glacier hazards at Belvedere glacier and the Monte Rosa east face, Italian Alps: Processes and mitigation. International Symposium, Interpraevent 2004 - Riva/Trient, 2004.

Kääb, A., Huggel, C., Fischer, L., Guex, S., Paul, F., Roer, I., Salzmann, N., Schlaefli, S., Schmutz, K., Schneider, D., Strozzi, T., and Weidmann, Y.: Remote sensing of glacier- and permafrostrelated hazards in high mountains: an overview, Nat. Hazards Earth Syst. Sci., 5, 527-554, 2005,

http://www.nat-hazards-earth-syst-sci.net/5/527/2005/.

Keller, F.: Automated mapping of mountain permafrost using the program PERMAMAP within the geographical information system ARC/INFO, Permafrost and Periglacial Processes, 3(2), 133-138, 1992.

Kneisel, C.: Permafrost in recently deglaciated glacier forefields measurements and observations in the eastern Swiss Alps and northern Sweden, Zeitschrift für Geomorphologie, 47, 3, 189305, 2003.

Margreth, S. and Funk, M.: Hazard mapping for ice and combined snow/ice avalanches - two case studies from the Swiss and Italian Alps, Cold Regions Science and Technology, 30, 159-173, 1999.

Matsuoka, N., Hirakawa, K., Watanabe, T., Haeberli, W., and Keller, F.: The role of diurnal, annual and millennial freeze-thaw cycles in controlling alpine slope instability, Proceedings of the Seventh International Conference on Permafrost, Yellowknife, Canada, Collection Nordicana, 57, 711-717, 1998.
Mazza, A.: Some results of recent investigations on Ghiacciaio del Belvedere (Anzasca Valley, Western Alps) taking into account the glacier mechanics, Geogr. Fis. Dinam. Quat., 23, 59-71, 2000.

Mercalli, L., Cat Berro, D., Montuschi, S., Castallano, C., Ratti, M., Di Napoli, G., Mortara, G., and Guidani, N.: Atlante climatico della Valle d'Aosta, Societa Meteorolgica Subalpina, Torino, 2003.

Noetzli, J., Hoelzle, M., and Haeberli, W.: Mountain permafrost and recent Alpine rock-fall events: a GIS-based approach to determine critical factors, in: 8th International Conference on Permafrost, Proceedings, edited by: Phillips, M., Springman, S., and Arenson, L., 2, Zurich, Swets \& Zeitlinger, Lisse, 827-832, 2003.

Paul, F., Kääb, A., Maisch, M., Kellenberger, T. W., and Haeberli, W.: Rapid disintegration of Alpine glaciers observed with satellite data, Geophys. Res. Lett., 31, L21402, doi:10.1029/2004GL020816, 2004.

Swisstopo, DHM25: Das digitale Hoehenmodell der Schweiz, Level 2, Bundesamt fuer Landestopographie, Wabern, Switzerland, 2002.

Tamburini, A. and Mortara, G.: The case of the "Effimero" Lake at Monte Rosa (Italian Western Alps): studies, field surveys, monitoring, in: Progress in Surface and Subsurface Water Studies at Plot and Small Basin Scale, Proceedings of the 10th ERB Conferece, Turin, 13-17 October 2004, Unesco, IHP-VI Technical Documents in Hydroloy, 77, 179-184, 2005.

Wegmann, M., Gudmundsson, G. H., and Haeberli, W.: Permafrost changes in rock walls and the retreat of Alpine glaciers: a thermal modelling approach, Permafrost and Periglacial Processes, 9, 23-33, 1998.

Zemp, M., Paul, F., Hoelzle, M., and Haeberli, W.: Glacier fluctuations in the European Alps 1850-2000: an overview and spatiotemporal analysis of available data, in: The darkening peaks: Glacial retreat in scientific and social context, edited by: Orlove, B., Wiegandt, E., and Luckman, B., University of California Press, in press, 2006. 